\title{
iCRESTRIGRS: a coupled modeling system for cascading flood-landslide disaster forecasting
}

\author{
Ke Zhang ${ }^{1,2,3}$, Xianwu Xue ${ }^{2}$, Yang Hong ${ }^{2,5}$, Jonathan J. Gourley ${ }^{4}$, Ning Lu ${ }^{6}$, Zhanming Wan ${ }^{2}$, Zhen Hong ${ }^{2}$, and \\ Rick Wooten ${ }^{7}$ \\ ${ }^{1}$ Cooperative Institute for Mescoscale Meteorological Studies, University of Oklahoma, Norman, OK 73072, USA \\ ${ }^{2}$ Hydrometeorology and Remote Sensing (HyDROS) Laboratory, School of Civil Engineering and Environmental Science, \\ and Advanced Radar Research Center, University of Oklahoma, Norman, OK 73072, USA \\ ${ }^{3}$ State Key Laboratory of Hydrology-Water Resources and Hydraulic Engineering, Hohai University, Nanjiang, \\ Jiangsu, 210098, China \\ ${ }^{4}$ NOAA/National Severe Storms Laboratory, Norman, OK 73072, USA \\ ${ }^{5}$ Department of Hydraulic Engineering, Tsinghua University, Beijing, China \\ ${ }^{6}$ Department of Civil \& Environmental Engineering, Colorado School of Mines, Golden, CO 80401, USA \\ ${ }^{7}$ North Carolina Geological Survey, North Carolina Department of Environmental Quality, Swannanoa, NC 28778, USA
}

Correspondence to: Ke Zhang (kezhang@ou.edu) and Yang Hong (yanghong@ou.edu)

Received: 22 March 2016 - Published in Hydrol. Earth Syst. Sci. Discuss.: 19 April 2016

Revised: 30 September 2016 - Accepted: 23 November 2016 - Published: 20 December 2016

\begin{abstract}
Severe storm-triggered floods and landslides are two major natural hazards in the US, causing property losses of USD 6 billion and approximately 110-160 fatalities per year nationwide. Moreover, floods and landslides often occur in a cascading manner, posing significant risk and leading to losses that are significantly greater than the sum of the losses from the hazards when acting separately. It is pertinent to couple hydrological and geotechnical modeling processes to an integrated flood-landslide cascading disaster modeling system for improved disaster preparedness and hazard management. In this study, we developed the iCRESTRIGRS model, a coupled flash flood and landslide initiation modeling system, by integrating the Coupled Routing and Excess STorage (CREST) model with the physically based Transient Rainfall Infiltration and Grid-Based Regional Slope-Stability (TRIGRS) landslide model. The iCRESTRIGRS system is evaluated in four river basins in western North Carolina that experienced a large number of floods, landslides and debris flows triggered by heavy rainfall from Hurricane Ivan during 16-18 September 2004. The modeled hourly hydrographs at four USGS gauge stations show generally good agreement with the observations during the entire storm period. In terms of landslide prediction in this case study, the coupled model has a global accuracy of $98.9 \%$ and a true positive rate of
\end{abstract}

$56.4 \%$. More importantly, it shows an improved predictive capability for landslides relative to the stand-alone TRIGRS model. This study highlights the important physical connection between rainfall, hydrological processes and slope stability, and provides a useful prototype model system for operational forecasting of flood and landslide.

\section{Introduction}

Severe flooding and landslides are two major natural hazards in the US and the world. Flooding causes property losses of USD 3.7 billion and approximately 110 fatalities per year nationwide (Ashley and Ashley, 2008), while landslides are responsible for 25-50 deaths and damage exceeding USD 2 billion annually (Spiker and Gori, 2003). Shallow landslides induced by heavy rainfall have posed significant threats to human lives and property worldwide (Hong et al., 2006; Kirschbaum et al., 2010). Moreover, heavy rainfall, floods and landslides often occur in a cascading manner, where a relatively low-consequence event like heavy rainfall could trigger a severe flood and/or landslide that poses significant risk to an affected community. Losses resulting from the combined hazards may be significantly greater than 
the sum of the losses from the hazards if acting separately. One example is the intense precipitation in the Colorado Front Range on 11-12 September 2013 that triggered flash floods and at least 1138 debris flows, resulting in 8 fatalities and more than 20000 buildings, 485 miles of roads and 50 bridges either damaged or destroyed (Coe et al., 2014). Another example of the devastating impacts of cascading multiple hazards: rain from the remnants of hurricanes Frances and Ivan triggered 400 reported slope failures of various types in the Blue Ridge Mountains of North Carolina, and at least 33 debris flows and major floods in Macon County, causing 5 deaths, destroying 16 homes, and damaging infrastructure (Wooten et al., 2008; Bauer et al., 2012). Such events make it critical to provide the public with riskinformed forecasting and warning systems in which multihazard threats are assessed and quantified.

According to a global natural disaster synthesis report (Dilley et al., 2005), over 790 million people are exposed to more than one natural hazard, based on the past 2 decades of historical loss data. Concurrent or time-lagged cascading multi-hazards are worldwide phenomena. In spite of their cascading nature, forecasts and warnings and risk assessments for such events conventionally are oriented towards single hazards, treating the cascading events as independent phenomena (Hsu et al., 2011; Wastl et al., 2011). One example is the severe storm system accompanied by a deadly tornado, heavy rain, and flash flooding that occurred in Oklahoma City (OKC) on 31 May 2013, in which more people were killed unexpectedly by the flash flooding than by the tornado, making it the deadliest flooding event that has ever occurred in OKC. This is partly due to the fact that the storm (accompanied by heavy precipitation and the tornado) and flash flood were forecasted by two separate warning systems and their warnings were issued separately (Uccellini et al., 2014); the public was well aware of the tornado threat but largely unaware of the flood threat in spite of several National Weather Service (NWS) products and outreach efforts (Uccellini et al., 2014). Moreover, the public's attention was mostly drawn to the tornado warnings (not to the flash flooding threat) mainly because this storm occurred only 10 days after the disastrous EF-5 tornado which devastated Moore, OK, and resulted in 24 fatalities and USD 2 billion in property damage. Although several recent studies have investigated multi-hazards and multi-hazard risk assessment (Budimir et al., 2014; Gill and Malamud, 2014; May, 2007; Mignan et al., 2014), these multi-hazard studies are still in the early stages of conceptual development (Gill and Malamud, 2014; Kappes et al., 2010). Knowledge gaps and disciplinary barriers in the development of multi-hazard approaches remain formidable. It is essential to understand the cascading effects of multiple natural hazards in an integrated way in order to accurately forecast their occurrence and assess their potential risks and societal impacts.

Hydrological models have been used for operational flood forecasting since the development of the first watershed hy- drological model in 1966 (Crawford and Linsley, 1966). Hydrological models have evolved from lumped-process models (Williams and Hann, 1978; Sugawara et al., 1984) to semi-distributed models (Beven and Kirkby, 1979; Zhao et al., 1980) and fully distributed models (Abbott et al., 1986; Wigmosta et al., 1996; Wang et al., 2011). Several regional to global real-time flood forecasting systems using hydrological models as major tools have been implemented, including the NASA-University of Oklahoma Ensemble Framework For Flash Flood Forecasting (EF5) (Clark III et al., 2016), the Flooded Locations and Simulated Hydrographs (FLASH) project (Gourley et al., 2014), the European Commission Global Flood Awareness System (Alfieri et al., 2013), and the NASA-University of Maryland Global Flood Monitoring System (Wu et al., 2014), among others. In the last decade, physics-based, rainfall-triggered landslide models (Baum et al., 2010; Godt et al., 2009; Dietrich et al., 1995; Iverson, 2000; Liao et al., 2010; Lu and Godt, 2008; Raia et al., 2014) have been developed to simulate slope stability influenced by topography, geology, and hydrological processes. Some pioneering studies have been conducted to couple hydrological models with landslide or slope-stability models to link the hydrological process with soil mechanics. For example, Simoni et al. (2008) combined a distributed hydrological model called GEOtop with a geotechnical model for probabilistic estimation of landslide occurrence. Lanni et al. (2012) utilized a dynamic topographic hydrological model to describe the subsurface processes and linked it with a simple hillslope slope-stability model for modeling the initiation of shallow landslides. Arnone et al. (2011), Lepore et al. (2013), Camera et al. (2013), and Tao and Barros (2014) have also conducted similar studies among others. However, there is still much room for conducting studies on coupling hydrological models with landslide models for large-scale flood and landslide prediction (Bogaard and Greco, 2014).

In this study, we present a framework that couples an established distributed hydrological model - the Coupled Routing and Excess STorage distributed hydrological model (CREST) (Wang et al., 2011) - with a well-known landslide model - Transient Rainfall Infiltration and Grid-Based Regional Slope-Stability (TRIGRS) (Baum et al., 2010) - to realize systematic and dynamical simulation of hydrological processes and their effects on slope stability. This integrated, coupled system is designed to serve as a prototype model for potential operational use. The objectives of this study are (1) to develop a coupled flood-landslide forecasting model system that can be forced by satellite- or radar-based quantitative precipitation estimation (QPE) systems or can be easily forced with numerical weather prediction models or other weather models, and (2) to evaluate the performance of this coupled modeling system in forecasting streamflow and slope failures. 


\section{Methodology and data}

\subsection{Methodology}

In this study, we developed an integrated modeling system in which the CREST distributed hydrological model is coupled with the TRIGRS landslide forecasting model (Fig. 1); therefore, the system is called "integrated CREST-TRIGRS" or iCRESTRIGRS. The CREST and TRIGRS models are briefly introduced in the following two sub-sections, while the integration method is described in detail in Sect. 2.1.3.

\subsubsection{CREST model}

The CREST model is a grid-based distributed hydrological model developed by the University of Oklahoma (http: //hydro.ou.edu) and NASA SERVIR project team (www. servir.net). It partitions net precipitation into surface runoff and infiltration using the variable infiltration capacity curve (VIC), a concept originating from the Xinanjiang model (Zhao, 1992; Zhao et al., 1980) and later represented in the VIC model (Liang et al., 1994, 1996). The multi-linear reservoir concept (Wang et al., 2011) is used to represent surface and subsurface water storages in the CREST model. It uses a cell-to-cell routing scheme to route overland flow to downslope cells, where it is further partitioned into infiltration and overland flow moving downslope using the VIC-based runoff generation scheme; in this way, interaction between surface and subsurface water flow processes is accounted for (Wang et al., 2011; Shen et al., 2016). The SCE-UA (shuffled complex evolution method developed at the University of Arizona) optimization scheme (Duan et al., 1992) is implemented to automatically calibrate the distributed model parameters.

The CREST model has been widely used for regional to global studies, including flood inundation mapping over ungauged basins (Khan et al., 2011), statistical and hydrological evaluation of multi-satellite precipitation products (Xue et al., 2013), and detection and prediction of extreme flood events (Y. Zhang et al., 2015). It has also been implemented in several operational systems, such as the FLASH (Flooded Locations And Simulated Hydrographs) project (http://www. nssl.noaa.gov/projects/flash/) and a near real-time global hydrological simulation and flood monitoring demonstration system (http://eos.ou.edu).

\subsubsection{TRIGRS model}

The TRIGRS V2.0.06b model computes transient porepressure changes and attendant changes in the factor of safety (FS) due to rainfall infiltration using a two-layer system that consists of an unsaturated zone above a saturated zone (Baum et al., 2010). This model links analytical solutions for transient, unsaturated, vertical infiltration above the water table (Srivastava and Yeh, 1991) to pressure-diffusion solutions for pressure changes below the water table. The solutions are linked through a transient water table that rises as water accumulates at the base of the unsaturated zone. Pore pressures computed by the models are subsequently used in one-dimensional slope-stability computations to estimate the timing and locations of slope instability (Baum et al., 2010). The TRIGRS model assumes that water can infiltrate with a maximum infiltration rate, i.e., the saturated hydraulic conductivity $\left(K_{\mathrm{s}}\right)$ at each grid cell. It also has a simple surface runoff routing scheme for water movement from cells that have excess surface water to adjacent downslope cells where it can either infiltrate or flow farther downslope. A detailed description of the TRIGRS model can be found in Baum et al. $(2008,2010)$.

\subsubsection{Integrated model system}

We integrated the CREST and TRIGRS models through oneway coupling. In this way, the CREST model computes all hydrologic storages and fluxes, including interception by vegetation, infiltration, runoff generation, water routing, and re-infiltration of excess surface runoff from upstream cells to downstream cells, and provides the initial conditions, e.g., soil wetness and depth of water table (Fig. 1). The CREST model feeds infiltration and its history and soil moisture condition into the TRIGRS model; the TRIGRS model is then implemented to compute pore pressure and slope stability correspondingly. FS in iCRESTRIGRS is calculated in the same way that the TRIGRS model does. FS is calculated as the ratio of resisting basal Coulomb friction to gravitationally induced downslope basal driving stress (Baum et al., 2010). FS is calculated for transient pressure heads at multiple depths. In the unsaturated zone, a simple approximation for Bishop's effective stress parameter is used in computing FS. To compute FS above the water table, the matric suction in the FS computation equation is multiplied by Bishop's effective stress parameter. Further details can be found in Baum et al. (2010). The coupling between CREST and TRIGRS is seamlessly executed in a distributed fashion at every time step and continuously computes runoff, infiltration, FS, pore pressure, and other water balance components at each grid cell. As shown in Fig. 1, this integrated system has an open interface that provides a utility to couple this integrated model with any other numerical weather prediction (NWP) model, climate model, or radar-/satellite-based quantitative precipitation estimation (QPE) system that provides precipitation and other necessary weather data to form an operational real-time forecasting or nowcasting system.

As mentioned above, the original TRIGRS model has its own schemes to estimate infiltration and runoff routing. In TRIGRS, it is assumed that runoff occurs when the precipitation and runoff supplied to a cell exceed its infiltrability. The infiltrability is set to the saturated hydraulic conductivity $\left(K_{\mathrm{S}}\right)$ based on previous studies (Iverson, 2000; Hillel, 1982). The infiltration $(I)$ at each cell is computed as the sum of the precipitation $(P)$ plus any runoff from upslope cells $\left(R_{\mathrm{u}}\right)$, 


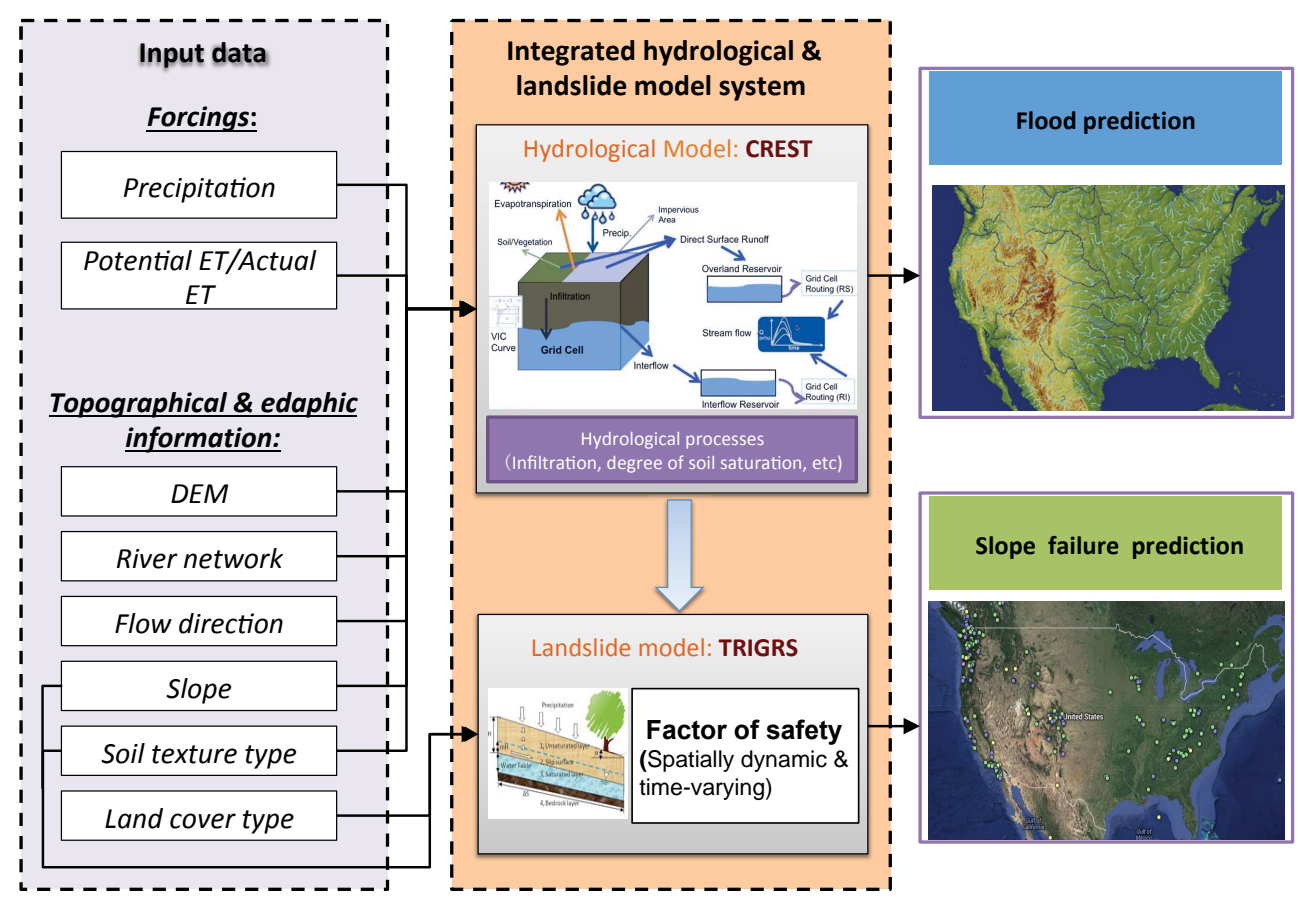

Figure 1. The framework of the proposed integrated CREST and TRIGRS modeling system, which is able to forecast flood and rainfalltriggered landslide events.

with the limitation that infiltration cannot exceed $K_{\mathrm{S}}$ (Baum et al., 2010):

$I= \begin{cases}P+R_{\mathrm{u}}, & P+R_{\mathrm{u}} \leq K_{\mathrm{s}} \\ K_{\mathrm{s}}, & P+R_{\mathrm{u}}>K_{\mathrm{s}}\end{cases}$

At each cell where $P+R_{\mathrm{u}}$ exceeds $K_{\mathrm{s}}$, the excess is considered runoff $\left(R_{\mathrm{d}}\right)$ and is diverted to adjacent downslope cells:

$R_{\mathrm{d}}=\left\{\begin{array}{ll}P+R_{\mathrm{u}}-K_{\mathrm{S}}, & P+R_{\mathrm{u}}-K_{\mathrm{S}}>0 \\ 0, & \text { otherwise }\end{array}\right.$.

Overland flow between adjacent cells is assumed to occur instantaneously; thus, the rate of overland flow is not considered or computed in TRIGRS. TRIGRS the enforces mass balance for each time step but does not carry runoff over from one time step to the next or track water that enters storm drains (Baum et al., 2008, 2010).

Unlike TRIGRS, the CREST model is a distributed hydrological model, which specializes in modeling all major surface hydrological processes. The rainfall-runoff generation processes in CREST start from the canopy interception. After $P$ passes the canopy layer, the excess precipitation that reaches the soil surface is net precipitation $\left(P_{\text {soil }}\right)$, which is further divided into surface runoff $(R)$ and infiltration $(I)$ according to the variable infiltration curve (VIC), a concept originating from the Xinanjiang model (Zhao, 1992; Zhao et al., 1980) and later represented in the VIC model (Liang et al., 1994, 1996). This model assumes that the point infiltration capacity $i$, which is the maximum water depth that can be stored in the soil column, varies over an area in the following relationship (Wang et al., 2011):

$i=i_{\mathrm{m}}\left[1-(1-a)^{\frac{1}{b}}\right]$,

where $i_{\mathrm{m}}$ is the maximum infiltration capacity of a cell and is determined by soil properties; $a$ is the fraction of a grid cell whose water capacity is less than or equal to the mean water capacity of the whole cell; and $b$ is an empirical shape parameter. The amount of water available for infiltration can therefore be calculated as follows (Wang et al., 2011):

$I=\left\{\begin{array}{l}W_{\mathrm{m}}-W, i+P_{\text {soil }} \geq i_{\mathrm{m}} \\ \left(W_{\mathrm{m}}-W\right)+W_{\mathrm{m}} \cdot\left[1-\frac{i+P_{\text {soil }}}{i_{\mathrm{m}}}\right]^{1+b}, i+P_{\text {soil }}<i_{\mathrm{m}}\end{array}\right.$,

where $W_{\mathrm{m}}$ and $W$ are the cell's maximum water capacity and total mean water of the three soil layers, respectively. The overland and subsurface flows are further separated from excess rain governed by the saturated soil hydraulic conductivity. Then the cell-to-cell routing of the overland and subsurface runoff is simulated using the multilinear reservoir method at each time step. CREST couples the runoff-generation process and the routing scheme to represent the interaction between the surface and subsurface flow in three better ways than simply routing surface flow downslope without considering its contribution to infiltration in downslope cells. First, overland runoff from upstream cells is treated as additional precipitation at the appropriate downstream cells available for infiltration and runoff parti- 


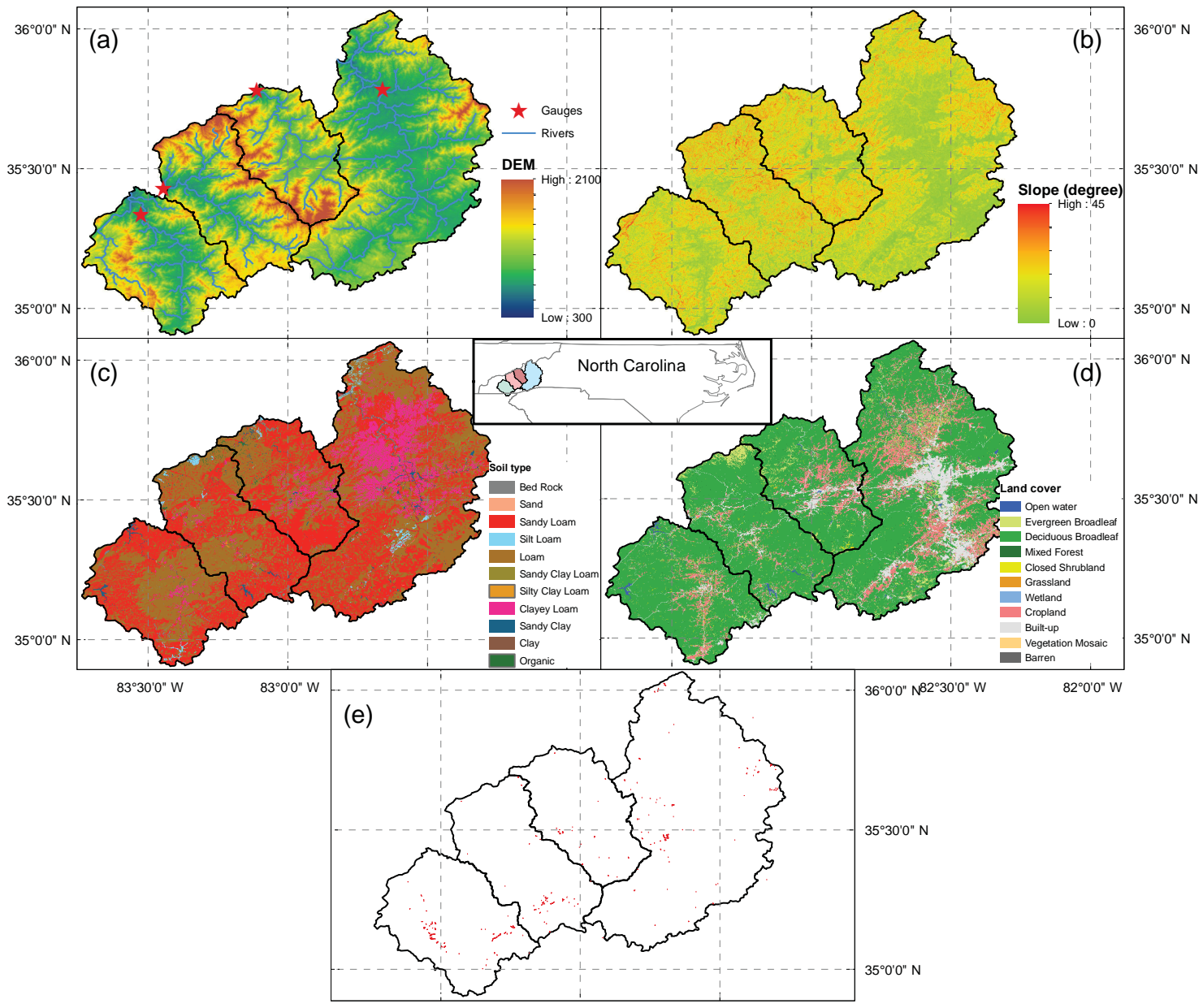

Figure 2. (a) Elevations, (b) slopes, (c) soil types, (d) land cover types, and (e) areal extent of reported individual slope movements during the study period in the study region, which include four river basins, the upper Little Tennessee River basin, Tuckasegee River basin, Pigeon River basin, and French Broad River Basin (from left to right); the inset shows the locations of the four basins within North Carolina.

tioning. Second, soil water can be increased by lateral interflow from upstream cells. Third, channel runoff from upstream cells contributes to the receptor cell's overland reservoir depth. This implemented cell-by-cell runoff routing enables this model to realistically compute the spatially and temporally varying values of runoff, soil moisture and infiltration. It also tracks the water movement through the basin.

In theory, replacing the simple infiltration and runoff routing schemes in TRIGRS with the more sophisticated runoff generation and routing methods in CREST will produce more realistic estimates of infiltration history in areas with nontrivial contributions of overland flow to infiltration. Moreover, the CREST model is able to simulate and provide necessary initial conditions and other inputs for the TRIGRS model. The iCRESTRIGRS model is, therefore, able to continuously and seamlessly simulate hydrological processes and solve pore pressure and factor of safety for each cell at each time step with available forcing data. The minimum forcing data required to run this model are only precipitation and evapotranspiration, making it an easily implementable model.

\subsection{Case study and data}

\subsubsection{Study area and case study}

We chose four adjacent river basins, the Upper Little Tennessee River basin, the Tuckasegee River basin, the Pigeon River basin, and the French Broad River basin, located in western North Carolina (Fig. 2a), as our study area. The drainage area of the four basins ranges between 1390 and $4050 \mathrm{~km}^{2}$.

Hurricane Ivan, the tenth most intense Atlantic hurricane ever recorded, passed through this region between 16 and 19 September 2004. It triggered over 110 landslides across the study region, and at least 33 debris flows occurred in Macon County, causing 5 deaths, destroying 16 homes, and damaging infrastructure (Wooten et al., 2008). Hurricane Ivan produced rainfall rates of $150-230 \mathrm{~mm} \mathrm{~h}^{-1}$ and precipitation 
totals from 52 to $351 \mathrm{~mm}$ across the study area (National Oceanic and Atmospheric Administration, 2004). The flood and landslide events triggered by the precipitation from Hurricane Ivan across western North Carolina serve as an ideal case study to test the integrated flood-landslide forecast system.

\subsubsection{Input and validation data}

Data used in this study include radar-measured rainfall- and satellite-based estimates of actual evapotranspiration, digital elevation models (DEM), land cover and soil texture maps, observed river streamflow from gauges, and an inventory of landslide events (Bauer et al., 2012). All gridded data were either downscaled or aggregated to a spatial resolution of $3 \operatorname{arcsec}\left(3^{\prime \prime}\right.$, i.e., $\sim 90 \mathrm{~m}$ ) to ensure the forcing and auxiliary data match with each other. Bilinear interpolation is the method for spatial downscaling in this study, whereas areaweighted resampling is used for aggregation.

The precipitation data were from the hourly, $4 \mathrm{~km}$ National Stage IV Quantitative Precipitation Estimation (QPE) product based on gauge and radar observations at NCEP (Lin and Mitchell, 2005). The Stage IV data were downscaled to $3^{\prime \prime}$ using bilinear interpolation. The actual evapotranspiration (ET) data were derived from a daily satellite remote-sensingbased ET record as input for the iCRESTRIGR model and are available at a spatial resolution of $8 \mathrm{~km}$ (Zhang et al., 2009, 2010; K. Zhang et al., 2015). The daily, $8 \mathrm{~km}$ ET data were first downscaled to a spatial resolution of $3^{\prime \prime}$ using bilinear interpolation and further downscaled to hourly resolution using the solar zenith angle as a function of solar declination, latitude, and hour angle of each grid cell.

The 3" DEM (Fig. 2a), flow direction, and flow accumulation data were obtained from the USGS HydroSHEDS $3^{\prime \prime}$ geo-referenced data sets (http://hydrosheds.cr.usgs.gov). These data serve as basic data for the distributed iCRESTRIGRS model to establish topological and geomorphological connections among grid cells and derive further topographical information such as slope (Fig. 2b). The map of soil type (Fig. 2c) was from the State Soil Geographic (STATSGO) data set, distributed by the Natural Resources Conservation Service (NRCS) of the US Department of Agriculture. The soil texture classes were converted to 12 USDA soil texture classes plus rock and organic matter. The land cover/land use map (Fig. 2d) was derived from the $30 \mathrm{~m} \mathrm{Na}$ tional Land Cover Database (NLDC) 2011 (Homer et al., 2015). Streamflow observations from four USGS streamflow gauges (no. 03503000 at Little Tennessee River, no. 03513000 at Tuckasegee River, no. 03460795 at Pigeon River, and no. 03453500 at French Broad River) were aggregated from $15 \mathrm{~min}$ to hourly resolution and serve as streamflow validation data for the model.

The locations and slope movement outlines of landslide events during Hurricane Ivan shown in Fig. 2e were identified by the North Carolina Geological Survey through field
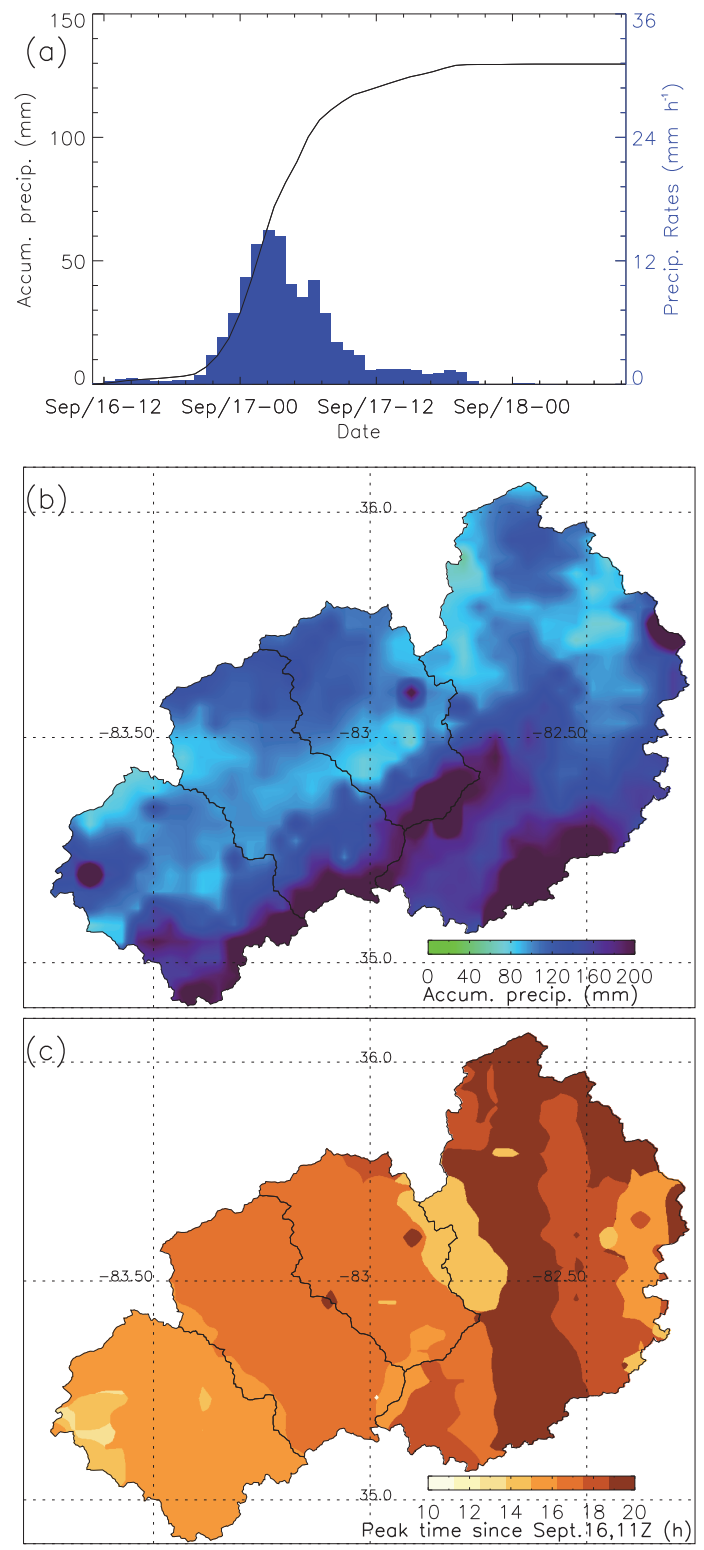

Figure 3. (a) Accumulated and hourly regional-average rainfalls during the 16-18 September storm period in the study region, (b) spatial pattern of accumulated rainfall during the storm period, and (c) spatial pattern of rain peak times since 16 September, 11:00 UTC.

surveys and other remote-sensing techniques (Wooten et al., 2008; Bauer et al., 2012). The areal extent of individual slope movements ranges from 22 to $139000 \mathrm{~m}^{2}$, with an average size of $6000 \mathrm{~m}^{2}$. The majority of these slope movement outlines have a long and narrow shape (Fig. 2e).

\subsubsection{Model parameters and initialization}

As the developed prototype model system is aimed at operational use over a large region, we determined the val- 
Table 1. Summary of key parameter values used in both TRIGRS and iCRESTRIGRS in this study.

\begin{tabular}{lrcccc}
\hline $\begin{array}{l}\text { USDA soil } \\
\text { texture } \\
\text { type }\end{array}$ & $\begin{array}{r}\text { Soil } \\
\text { cohesion } \\
(\mathrm{kPa})\end{array}$ & $\begin{array}{c}\text { Porosity } \\
\text { Hydraulic }\end{array}$ & $\begin{array}{c}\text { Saturated } \\
\text { conductivity }^{2} \\
\left(\mathrm{~m} \mathrm{~s}^{-1}\right)\end{array}$ & $\begin{array}{c}\text { Friction }^{-1} \\
\text { angle }^{1} \\
\left({ }^{\circ}\right)\end{array}$ & $\begin{array}{c}\text { Soil dry unit } \\
\text { weight }^{1} \\
\left(\mathrm{kN} \mathrm{m}^{-3}\right)\end{array}$ \\
\hline Sand & 5.0 & 0.43 & $2.44 \times 10^{-5}$ & 40.0 & 21.0 \\
Loamy sand & 7.5 & 0.42 & $1.78 \times 10^{-5}$ & 28.5 & 20.5 \\
Sandy loam & 6.0 & 0.40 & $1.02 \times 10^{-5}$ & 32.0 & 15.0 \\
Silt loam & 9.0 & 0.46 & $2.50 \times 10^{-6}$ & 24.0 & 14.0 \\
Loam & 10.0 & 0.43 & $4.53 \times 10^{-6}$ & 22.5 & 13.0 \\
Sandy clay loam & 29.0 & 0.39 & $6.59 \times 10^{-6}$ & 20.0 & 15.0 \\
Silty clay loam & 50.0 & 0.48 & $1.44 \times 10^{-6}$ & 16.5 & 14.0 \\
Clayey loam & 35.0 & 0.46 & $2.72 \times 10^{-6}$ & 20.0 & 14.0 \\
Sandy clay & 24.5 & 0.41 & $4.31 \times 10^{-6}$ & 22.5 & 18.5 \\
Silty clay & 30.0 & 0.49 & $1.06 \times 10^{-6}$ & 18.5 & 18.0 \\
Clay & 40.0 & 0.47 & $1.31 \times 10^{-6}$ & 16.5 & 19.5 \\
Silt & 9.0 & 0.52 & $2.05 \times 10^{-6}$ & 26.5 & 16.5 \\
\hline
\end{tabular}

${ }^{1}$ Values were roughly set to the means of the ranges determined from Das (2008), Hough (1969), Terzaghi et al. (1996) and Dysli, (2000); ${ }^{2}$ values were estimated by the pedotransfer equations of Cosby et al. (1984) using the mean sand and clay fractions of each soil class.

ues of model parameters at each grid cell based on its soil class rather than using very limited local measured values. For this purpose, we built a parameter look-up table based on the USDA textural soil classification. Table 1 summarizes the values of key common parameters used in both TRIGRS and iCRESTRIGRS. The values of all these parameters were roughly estimated as the means of their value ranges determined from the literature. Parameter $W_{\mathrm{m}}$ of the iCRESTRIGRS model was determined from topography using the a priori estimation method developed by Yao et al. (2012), while parameter $b$ is set to a constant (1.5) across the study region based on our past experience. For the rest of the iCRESTRIGRS parameters that are inherited from CREST, we determined their distributed values using the parameter look-up table provided by the CREST user manual (Xue et al., 2015) based on the land cover map and the soil texture map.

Because all model parameters were determined from soil types a priori, we did not conduct model calibration in this study. To minimize the uncertainty in the initial conditions, the iCRESTRIGRS model was spun up for 1 year beforehand.

\subsection{Statistical metrics for evaluating model performance}

To evaluate the performance of this integrated model system, we applied a suite of statistical metrics to evaluate the model results. We computed relative bias, Pearson correlation coefficient (CC), and Nash-Sutcliffe coefficient of efficiency (NSCE) for the modeled hourly discharge series using the four USGS gauge stations.

To quantitatively measure the predictive capabilities of the models for landslide prediction, we calculated the confusion matrix through comparison between the binary predictions of slope failure and the landslide inventory database. The confusion matrix consists of four possible outcomes (Fawcett, 2006): (1) a modeled landslide is a true one (true positive, TP), (2) a modeled landslide is a false one (false positive, FP), (3) an observed landslide is not captured by the model (false negative, FN), and (4) a grid cell is stable in both model and observation (true negative, TN). Based on the confusion matrix, a series of indices can be calculated:

$$
\begin{aligned}
& \mathrm{TPR}=\mathrm{TP} /(\mathrm{TP}+\mathrm{FN}) \\
& \mathrm{TNR}=\mathrm{TN} /(\mathrm{TN}+\mathrm{FP}) \\
& \text { and efficiency }=(\mathrm{TP}+\mathrm{TN}) /(\mathrm{TP}+\mathrm{TN}+\mathrm{FP}+\mathrm{FN}),
\end{aligned}
$$

where TPR is the true positive rate and also called sensitivity, and TNR is the true negative rate and also called specificity. The sensitivity statistic measures the percentage of positive cases correctly predicted, while the specificity statistic quantifies the percentage of negative cases correctly predicted (Begueria, 2006; Fawcett, 2006). The receiver operating characteristic (ROC) curve analysis was further applied to evaluate model results for landslide predictions and to compare differences between the TRIGRS and iCRESTRIGRS models. A ROC curve consists of TPR and TNR pairs, which are computed from the respective confusion matrices for different cutoff values. In our case, the cutoff variable is FS. A ROC curve shifted towards the upper-right corner means better model performance. The better the performance of the model, the larger the area under the ROC curve (AUC); therefore, the AUC index serves as a global statistical accuracy indicator for the model. 

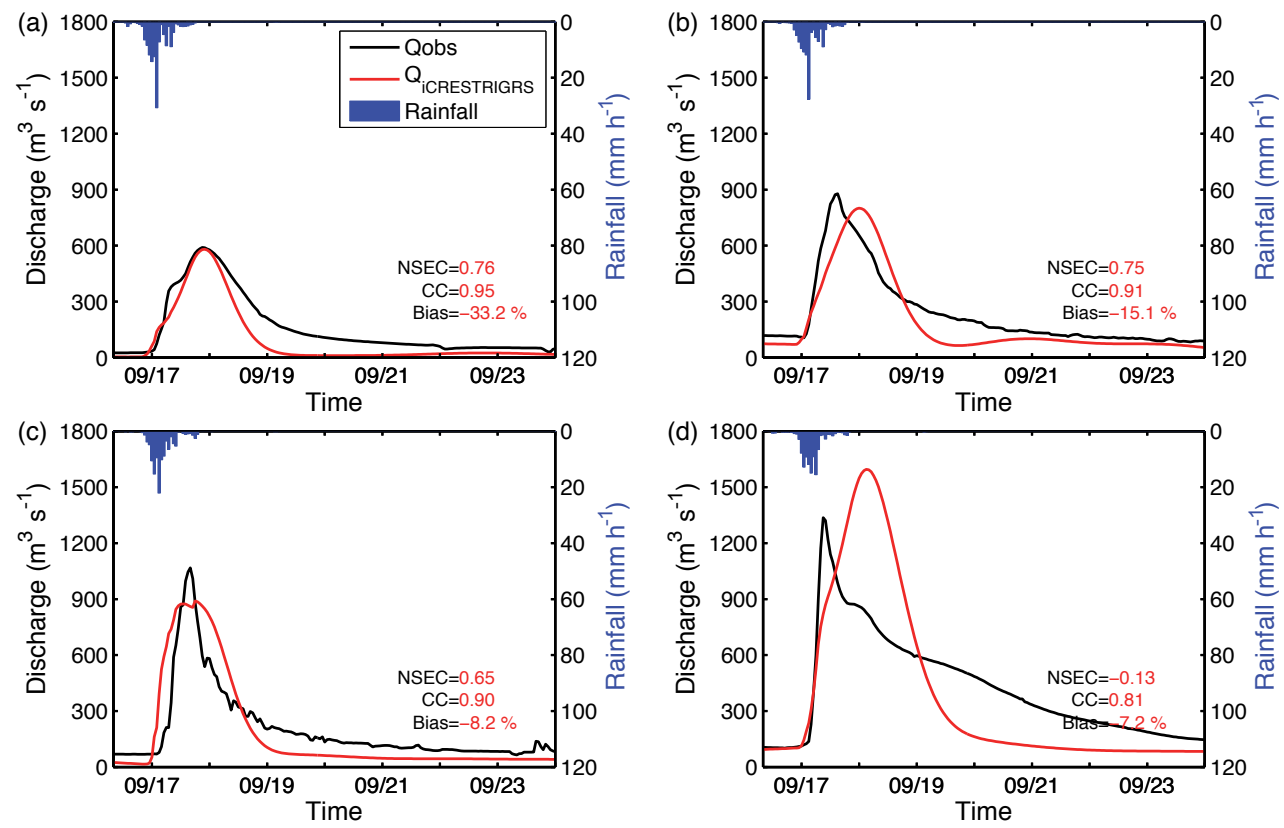

Figure 4. Observed and modeled hydrographs and basin-average rainfall rates at the (a) upper Little Tennessee River basin, (b) Tuckasegee River basin, (c) Pigeon River basin, and (d) French Broad River basin.

\section{Results}

\subsection{Characteristics of the Hurricane Ivan induced storm}

Hurricane Ivan passed through western North Carolina between 16 and 18 September 2004. The storm in this region started around 11:00 UTC 16 September 2004 and completely ceased around 03:00 UTC 18 September, while the majority of rainfall occurred in the first $24 \mathrm{~h}$ (Fig. 3a). It brought an average rainfall of $\sim 130 \mathrm{~mm}$ within $24 \mathrm{~h}$ across the region (Fig. 3a), while accumulated rainfall reached maximum values in the southern parts of the four river basins (Fig. 3b). The storm roughly moved from southwest to northeast (Fig. 3c); differences in peak time of rainfall across this region can be as large as $5 \mathrm{~h}$ (Fig. 3c). The storm was rapid and intense.

\subsection{Model evaluation and comparison}

The modeled hourly discharge series between 16 and 24 September 2004 by the iCRESTRIGRS model were compared with the observations at the four USGS gauge stations (Fig. 4a-d). The modeled hydrographs show generally good agreement with the observations. $\mathrm{CC}$ is larger than 0.80 at all stations. Relative bias falls within $\pm 34 \%$. The NSCE values at three stations except the one located at French Broad River are larger than or equal to 0.65 . The low NSCE value at the French Broad River is largely due to a time shift between modeled and observed peak discharges (Fig. 4d). The delayed peak discharge in the model implies that there is likely some uncertainty in the flow concentration and routing module of the iCRESTRIGRS model. In addition, uncertainty in the spatial distribution of Stage IV rainfall data can also cause some uncertainty in the process of flow concentration. In general, the above results indicate that the iCRESTRIGRS model is generally capable of simulating runoff process well and predicting the flood events.

In the model, whenever the FS value is less than 1.0, the regolith that covers the sloping ground surface is predicted to fail and there is a corresponding landslide. Figure 5a and $\mathrm{b}$ show the maps of minimum FS values during the whole storm period modeled by TRIGRS and iCRESTRIGRS, respectively. In Fig. 5, the reported landslide events are plotted as magenta circles. When we actually evaluated the model performance, we compared the model results with the surveyed slope movement outlines. Therefore, we regard the model as successfully predicting a real landslide if any of the grid cells that overlap with the slope movement outline of this landslide has a FS value of $<1$; on the other hand, the model is believed to have failed to capture a landslide event if none of these cells overlapping the slope movement outline is simulated as unstable. The spatial distribution of reported landslides generally corresponds to the spatial patterns of model minimum FS values (Fig. 5a, b). In other words, the actual landslides are mostly located in the areas in which models predict unstable or close to unstable conditions (Fig. 5a, b). A notable difference in the spatial patterns of FS by the two models is that more areas in TRIGRS (Fig. 5a) have unstable slopes than in iCRESTRIGRS (Fig. 5b). This confirms that the factor of safety computed by the models is sensitive to 

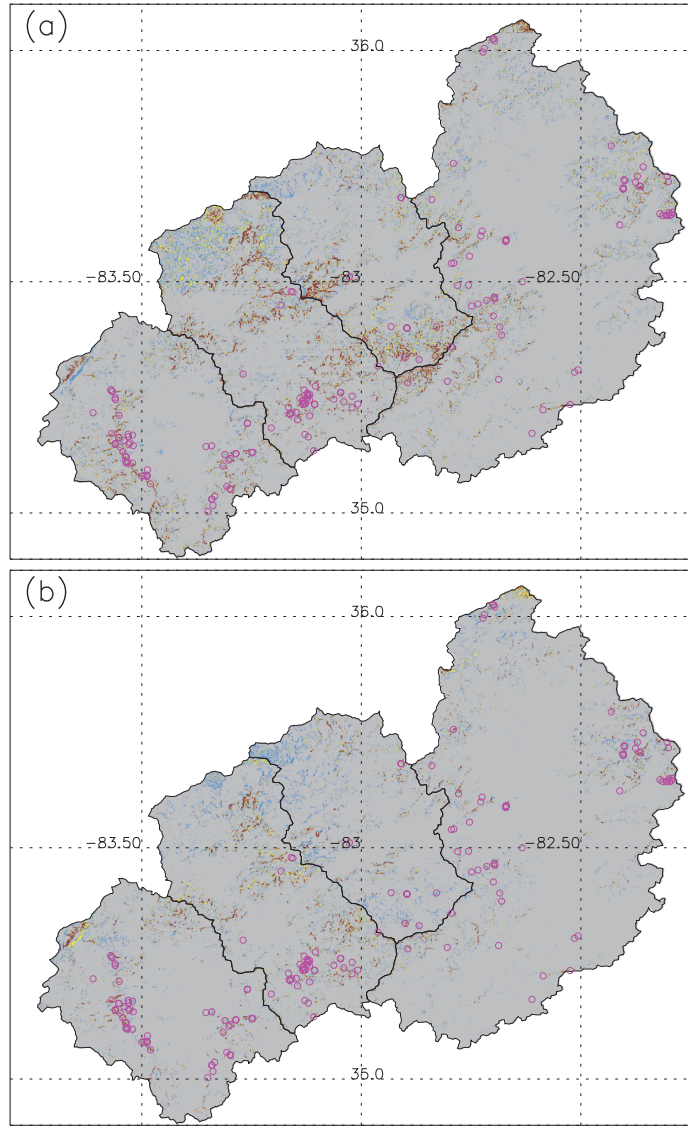

$1.0 \quad 1.0-1.15 \square 1.15-1.3 \quad>1.3$ oReported Iandslides

Figure 5. Comparisons (a) between TRIGRS modeled FS and reported landslide events, and (b) between iCRESTRIGRS modeled FS and reported landslide events.

hydrological processes, in particular the infiltration process, because the largest difference between TRIGRS and iCRESTRIGRS lies in the way that infiltration and runoff routing are computed. For the TRIGRS model, the TPR, TNR, and accuracy statistics are 59.0, 97.5, and $97.7 \%$, respectively, when FS $=1$ is set as a cutoff value for slope stability. For the iCRESTRIGRS model, the three metrics are 56.4, 98.8, and $98.9 \%$. These results indicate that the iCRESTRIGRS model shows generally better results and that coupling the CREST distributed hydrological model with the TRIGRS model leads to an improved model performance, at least for this case study.

The ROC analysis demonstrates that the coupled system generally has higher specificity relative to the original TRIGRS model (Fig. 6). The AUC values for the TRIGRS and iCRESTRIGRS models are 0.90 and 0.92 , respectively, suggesting that iCRESTRIGRS performs better than TRIGRS in this case study. As mentioned above and shown in Fig. 7, the largest difference between the two models lies in the model infiltration values. It is clear that the simple infiltration

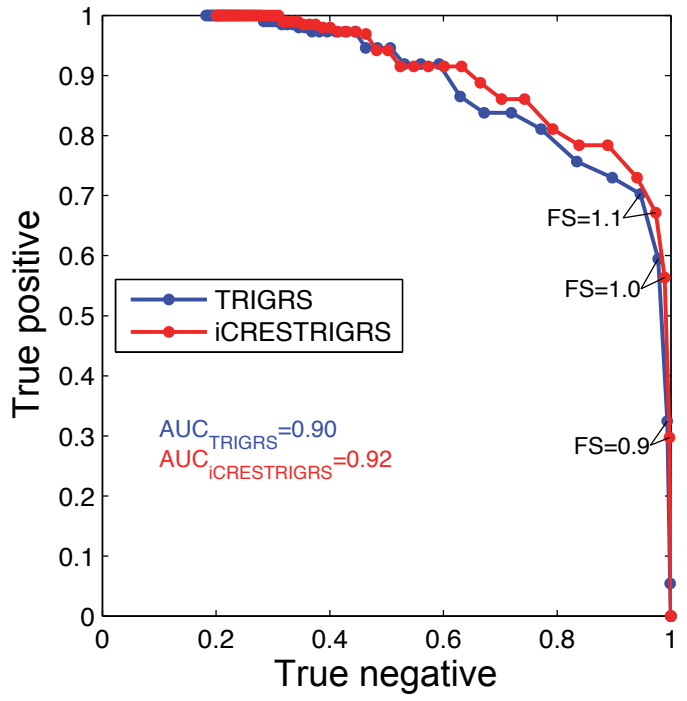

Figure 6. Receiver operator characteristic (ROC) graph comparing slope-stability results from the TRIGRS and iCRESTRIGRS models.

and rain excess routing schemes implemented in the TRIGRS model lead to higher values of infiltration than in the iCRESTRIGRS model (Fig. 7a). The regional average accumulated infiltration during the 16-18 September storm modeled by TRIGRS is $104.9 \mathrm{~mm}$, while the value modeled by iCRESTRIGRS is just half of it, i.e., $52.2 \mathrm{~mm}$ (Fig. 7a). The larger infiltration rate in TRIGRS than in iCRESTRIGRS appears across the whole region (Fig. 7b, c). This explains why the TRIGRS results have generally lower FS values than the iCRESTRIGRS results and why TRIGRS has a higher false positive rate than iCRESTRIGRS (Fig. 5).

\subsection{Evolution of modeled cascading flood-landslide hazards}

We further investigated the evolution of the storm in terms of accumulated rainfall during a $6 \mathrm{~h}$ period and the corresponding responses of hydrological processes (e.g., infiltration and overland runoff), slope stability, and pressure modeled by the iCRESTRIGRS model (Fig. 8). In Fig. 8, the rainfall and infiltration are $6 \mathrm{~h}$ accumulated values, while overland runoff is the average value during each $6 \mathrm{~h}$ period. Factor of safety is the minimum value during each period, while pore pressure is the value at the depth and at the time corresponding to the lowest FS.

During the first $6 \mathrm{~h}$ period, rainfall intensities are low across the region. The accumulated rainfall is generally less than $10 \mathrm{~mm}$ during this period (Fig. 8). In response to this, the modeled infiltration rate and its accumulated value are low as well, while simulated overland runoff mainly appears in the main river channels. Very few unstable slopes appear across this region in the model and pore pressure is generally low. During the second $6 \mathrm{~h}$ period, rainfall rate and modeled in- 

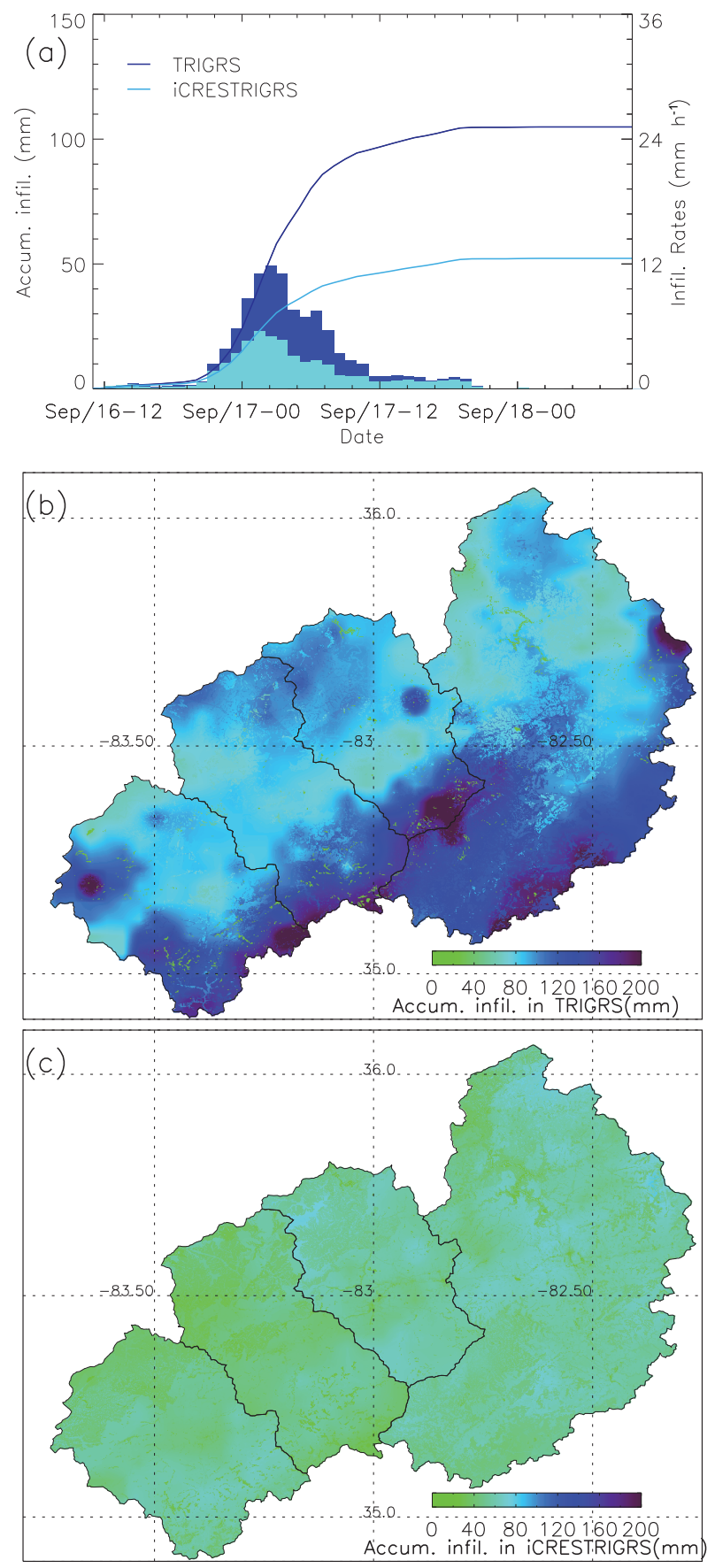

Figure 7. (a) Accumulated and hourly infiltration values from the TRIGRS and iCRESTRIGRS models, and spatial patterns of accumulated infiltrations from the (b) TRIGRS and (c) iCRESTRIGRS models.

filtration rate increase to some extent, especially in the Little Tennessee River and Tuckasegee River basins. The model results show that overland flow starts to appear in the small tributaries and creeks (Fig. 8). Pore pressure reaches high values in some areas of the Little Tennessee River and Tuckasegee
River basins, resulting in some unstable slopes. These unstable slopes are largely located in the areas with steep slopes. During the third $6 \mathrm{~h}$ period, rainfall reaches a maximum and has an accumulated value larger than $30 \mathrm{~mm}$ over most of the region. Correspondingly, infiltration rates also reach maximum and overland runoff appears everywhere, with rapid rises of streamflow in the drainage network. The number of modeled landslides has increased dramatically, accompanied by large increases in pore pressures. As the storm enters the fourth $6 \mathrm{~h}$ period, rainfall and infiltration intensities decline but still maintain high levels. Pore pressures in some regions continue to rise, resulting in some new landslides. During the fifth period, rainfall and infiltration intensities are reduced greatly. Runoff on the land and in many upstream reaches of these rivers starts to subside. Pore pressure declines in many areas, but remains high in some areas in response to accumulative infiltration processes. The number of modeled landslides during this period also decreases. The detailed analyses of rainfall and modeled hydrological and geotechnical responses on a phase-by-phase basis show that the model results show reasonable responses to the evolution of the storm in space and time. It also emphasizes the cascading nature of rainfall-triggered floods and shallow landslides.

\section{Conclusion and discussion}

This study presents a new, coupled model system, which integrates the CREST distributed hydrological model with the TRIGRS landslide model for flood and landslide forecasting. Driven by the hydrological states and fluxes modeled by CREST, iCRESTRIGRS improves over TRIGRS by providing more accurate initial conditions such as degree of soil saturation and depth of the water table. Furthermore, CREST specializes in the simulation of hydrological processes and fluxes and can thus provide more realistic hydrological fluxes such as infiltration for TRIGRS, leading to better accuracy for landslide forecasting. The case study demonstrates that the integrated model shows better results than the stand-alone TRIGRS model for landslide forecasting.

The modeling system presented in this study is also developed as a framework and is able to adopt other hydrological models and landslide models as alternatives to compute hydrological processes and soil stability. Therefore, this can be easily expanded to build an ensemble-based system. This coupled modeling system has low requirements for input data as well, making it easy to couple with other numerical weather prediction models and real-time QPE forcings.

It is worth noting that there is still much room for improving the predictive capabilities of iCRESTRIGRS for flood and landslide forecasting. In particular, the true positive rate for landslide forecasting in iCRESTRIGRS in the case study is not high. This can be improved through further parameter optimization and/or implementation of reliable pedotransfer functions. In addition, better characterization of soil proper- 


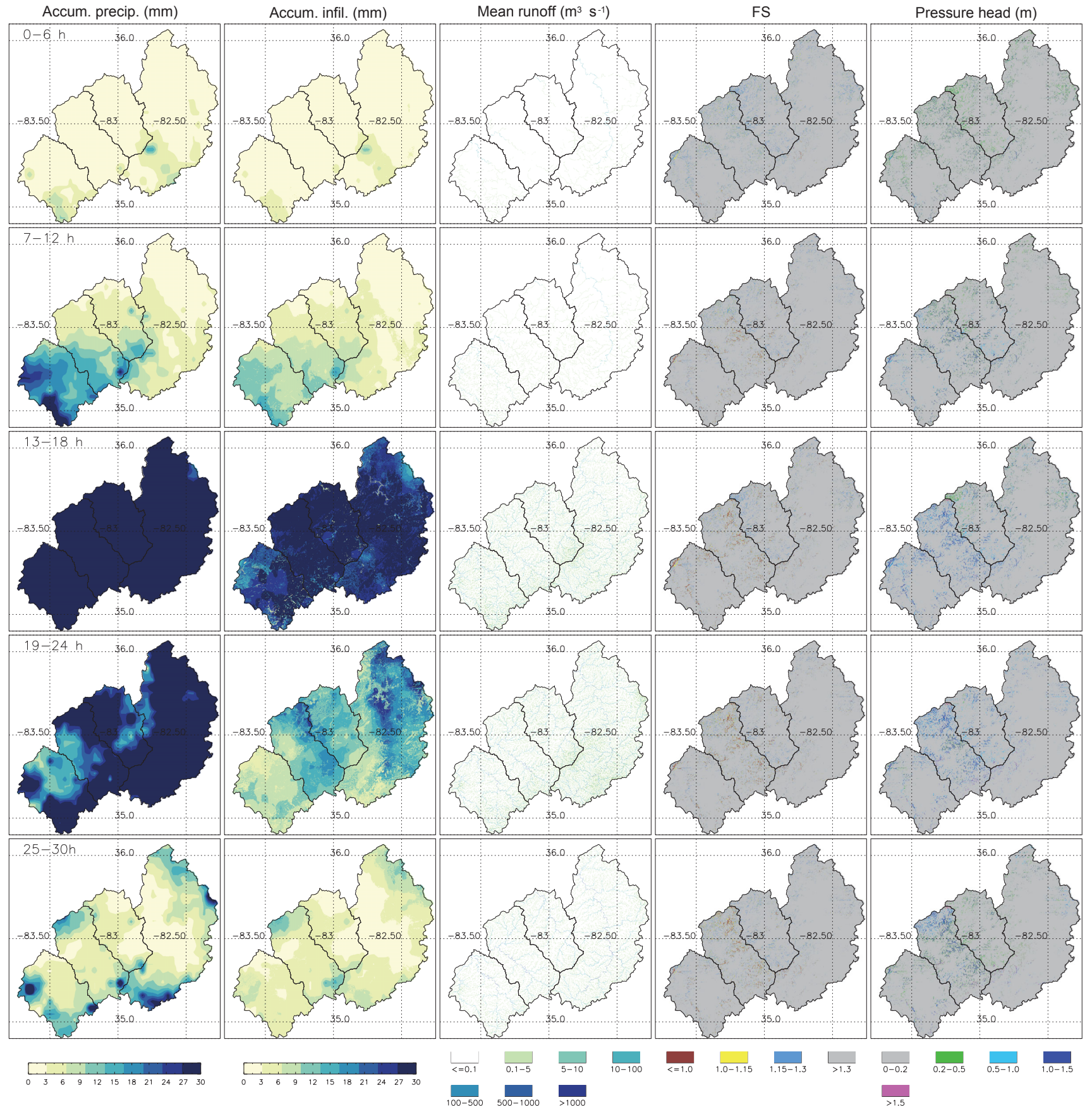

Figure 8. Maps showing the evolution of storms (rainfall), hydrological responses such as infiltration and runoff, slope stability, and pressure head at the depth corresponding to the lowest factor of safety.

ties, improved model formulation, and more information on fine-scale topography likely help improve model accuracy, because hydrological processes are highly scale-dependent (Yu et al., 2014). In particular, slope stability is highly dependent on the steepness of hillslopes, which is highly dependent on the model's spatial resolution. In this study, the grid spacing is set to $90 \mathrm{~m}$ rather than a finer resolution be- cause we were limited by computational burden; plus, this prototype system is designed from operational use, so it is impractical to run this system with an extremely fine resolution over a large region. However, a nested modeling approach, which executes the hydrological model at a coarser resolution, allows the landslide model to be executed at finer and coarser resolutions in the landslide prone areas and sta- 
ble areas, respectively. Introducing parallel computing into the iCRESTRIGRS model using a new message passing interface (MPI) version of TRIGRS (Alvioli and Baum, 2016) will facilitate the application of the iCRESTRIGRS model at a finer resolution. Additional evaluation of this model in larger regions and under different conditions will better support the predictive capability and robustness of this model.

\section{Data availability}

The DEM data are available from http://hydrosheds.cr.usgs. gov. The streamflow data are provided by the USGS (https: //waterdata.usgs.gov), while the landcover data are available through http://www.mrlc.gov/nlcd2011.php. Landslide records are available upon request to Rick Wooten, while all other data are available upon request to Ke Zhang.

Acknowledgements. This research was funded by the NOAA/Office of Oceanic and Atmospheric Research under NOAA-University of Oklahoma Cooperative Agreement no. NA14OAR4830100, the NASA Surface and Interior program (NNH10ZDA001NESI), Fundamental Research Funds for the Central Universities (2015B28514) and the National Natural Science Foundation of China (71461010701).

Edited by: T. Bogaard

Reviewed by: two anonymous referees

\section{References}

Abbott, M. B., Bathurst, J. C., Cunge, J. A., O’Connell, P. E., and Rasmussen, J.: An introduction to the European Hydrologic System - Systeme Hydrologique Europeen, "SHE" 1: history and philosophy of a physically based distributed modeling system, J. Hydrol., 87, 45-59, 1986.

Alfieri, L., Burek, P., Dutra, E., Krzeminski, B., Muraro, D., Thielen, J., and Pappenberger, F.: GloFAS - global ensemble streamflow forecasting and flood early warning, Hydrol. Earth Syst. Sci., 17, 1161-1175, doi:10.5194/hess-17-1161-2013, 2013.

Alvioli, M. and Baum, R. L.: Parallelization of the TRIGRS model for rainfall-induced landslides using the message passing interface, Environ. Modell. Softw., 81, 122-135, 2016.

Arnone, E., Noto, L. V., Lepore, C., and Bras, R. L.: Physicallybased and distributed approach to analyze rainfall-triggered landslides at watershed scale, Geomorphology, 133, 121-131, 2011.

Ashley, S. T. and Ashley, W. S.: Flood fatalities in the United States, J. Appl. Meteorol. Clim., 47, 805-818, 2008.

Bauer, J. B., Fuemmeler, S. F., Wooten, R. M., Witt, A. C., Gillon, K. A., and Douglas, T. J.: Landslide hazard mapping in North Carolina - overview and improvements to the program, Proceedings of the 11th International Symposium on Landslides and 2nd North American Symposium on Landslides, Banff, Alberta, Canada, 2012, 257-263, 2012.

Baum, R. L., Savage, W. Z., and Godt, J. W.: TRIGRS-A Fortran program for transient rainfall infiltration and grid-based re- gional slope-stability analysis, Version 2.0, US Geological Survey Open-File Report, 2008-1159, 75, 2008.

Baum, R. L., Godt, J. W., and Savage, W. Z.: Estimating the timing and location of shallow rainfall-induced landslides using a model for transient, unsaturated infiltration, J. Geophys. Res., 115, F03013, doi:10.1029/2009jf001321, 2010.

Begueria, S.: Validation and evaluation of predictive models in hazard assessment and risk management, Nat. Hazards, 37, 315329, 2006.

Beven, K. J. and Kirkby, M. J.: A physically based, variable contributing area model of basin hydrology, Hydrological SciencesBulletin-des Sciences Hydrologiques, 24, 43-69, 1979.

Bogaard, T. and Greco, R.: Preface "Hillslope hydrological modelling for landslides prediction", Hydrol. Earth Syst. Sci., 18, 4185-4188, doi:10.5194/hess-18-4185-2014, 2014.

Budimir, M. E. A., Atkinson, P. M., and Lewis, H. G.: Earthquakeand-landslide events are associated with more fatalities than earthquakes alone, Nat. Hazards, 72, 895-914, 2014.

Camera, C., Apuani, T., and Masetti, M.: A coupled distributed hydrological-stability analysis on a terraced slope of Valtellina (northern Italy), Hydrol. Earth Syst. Sci. Discuss., 10, 2287 2322, doi:10.5194/hessd-10-2287-2013, 2013.

Clark III, R., Flamig, Z., Vergara, H., Hong, Y., Gourley, J. J., Mandl, D., Frye, S., Handy, M., and Patterson, M.: Hydrological Modeling and Capacity Building in the Republic of Namibia, B Am. Meteorol. Soc., doi:10.1175/BAMS-D-15-00130.1, 2016.

Coe, J. A., Kean, J. W., Godt, J. W., Baum, R. L., Jones, E. S., Gochis, D. J., and Anderson, G. S.: New insights into debrisflow hazards from an extraordinary event in the Colorado Front Range, GSA Today, 24, 4-10, 2014.

Cosby, B. J., Hornberger, G. M., Clapp, R. B., and Ginn, T. R.: A Statistical Exploration of the Relationships of Soil-Moisture Characteristics to the Physical-Properties of Soils, Water Resour. Res., 20, 682-690, 1984.

Crawford, N. H. and Linsley, R. S.: Digital simulation in hydrology: The Stanford Watershed Model IV, Technical Report No. 39, Department of Civil Engineering, Stanford University, Palo Alto, California, 1966.

Das, B.: Adanced soil mechanics, Taylor \& Francis, London, New York, 2008.

Dietrich, W. E., Reiss, R., Hsu, M. L., and Montgomery, D. R.: A Process-Based Model for Colluvial Soil Depth and Shallow Landsliding Using Digital Elevation Data, Hydrol, Process,, 9, 383-400, 1995.

Dilley, M., Chen, R. S., Deichmann, U., Lerner-Lam, A. L., Arnold, M., Agwe, J., Buys, P., Kjekstad, O., Lyon, B., and Yetman, G.: Natural disaster hotspots: a global risk analysis synthesis report, International Bank for Reconstruction and Development/The World Bank and Columbia University, Washington, DC, 2005.

Duan, Q. Y., Sorooshian, S., and Gupta, V.: Effective and Efficient Global Optimization for Conceptual Rainfall-Runoff Models, Water Resour. Res., 28, 1015-1031, 1992.

Dysli, M.: Swiss Standard SN 670 010b, Characteristic Coefficients of soils, Strasse und Verkehr, 86, 93-94, 2000.

Fawcett, T.: An introduction of ROC analysis, Pattern Recogn. Lett., 27, 861-874, 2006.

Gill, J. and Malamud, B. D.: Reviewing and visualizing the interactions of natural hazards, Rev. Geophys., 52, 680-722, 2014. 
Godt, J. W., Baum, R. L., and Lu, N.: Landsliding in partially saturated materials, Geophys. Res. Lett., 36, L02403, doi:10.1029/2008GL035996, 2009.

Gourley, J. J., Flamig, Z. L., Hong, Y., and Howard, K. W.: Evaluation of past, present and future tools for radar-based flash-flood prediction in the USA, Hydrolog. Sci. J., 59, 1377-1389, 2014.

Hillel, D.: Introduction to soil physics, Academic Press, San Diego, California, 1982.

Homer, C., Dewitz, J., Yang, L. M., Jin, S., Danielson, P., Xian, G., Coulston, J., Herold, N., Wickham, J., and Megown, K.: Completion of the 2011 National Land Cover Database for the Conterminous United States - Representing a Decade of Land Cover Change Information, Photogramm. Eng. Rem. S., 81, 345-354, 2015.

Hong, Y., Adler, R., and Huffman, G.: Evaluation of the potential of NASA multi-satellite precipitation analysis in global landslide hazard assessment, Geophys. Res. Lett., 33, 440-452, 2006.

Hough, B.: Basic soil engineering, Ronald Press Company, New York, 1969.

Hsu, W. K., Huang, P. C., Chang, C. C., Chen, C. W., Hung, D. M., and Chiang, W. L.: An integrated flood risk assessment model for property insurance industry in Taiwan, Nat. Hazards, 58, 12951309, 2011.

Iverson, R. M.: Landslide triggering by rain infiltration, Water Resour. Res., 36, 1897-1910, 2000

Kappes, M. S., Keiler, M., and Glade, T.: From single- to multihazard risk analyses: a concept addressing emerging challenges, in: Mountain Risks: Bringing Science to Society, edited by: Malet, J. P., Glade, T., and Casagli, N., CERG Editions, Strasbourg, France, 351-356, 2010.

Khan, S. I., Hong, Y., Wang, J. H., Yilmaz, K. K., Gourley, J. J., Adler, R. F., Brakenridge, G. R., Policelli, F., Habib, S., and Irwin, D.: Satellite Remote Sensing and Hydrologic Modeling for Flood Inundation Mapping in Lake Victoria Basin: Implications for Hydrologic Prediction in Ungauged Basins, IEEE T. Geosci. Remote, 49, 85-95, 2011.

Kirschbaum, D. B., Adler, R., Hong, Y., Hill, S., and Lerner-Lam, A.: A global landslide catalog for hazard applications: method, results, and limitations, Nat. Hazards, 52, 561-575, 2010.

Lanni, C., Borga, M., Rigon, R., and Tarolli, P.: Modelling shallow landslide susceptibility by means of a subsurface flow path connectivity index and estimates of soil depth spatial distribution, Hydrol. Earth Syst. Sci., 16, 3959-3971, doi:10.5194/hess-163959-2012, 2012.

Lepore, C., Arnone, E., Noto, L. V., Sivandran, G., and Bras, R. L.: Physically based modeling of rainfall-triggered landslides: a case study in the Luquillo forest, Puerto Rico, Hydrol. Earth Syst. Sci., 17, 3371-3387, doi:10.5194/hess-17-3371-2013, 2013.

Liang, X., Lettenmaier, D. P., Wood, E. F., and Burges, S. J.: A simple hydrologically based model of land surface water and energy fluxes for general circulation models, J. Geophys. Res., 99, 14415-14428, 1994.

Liang, X., Wood, E. F., and Lettenmaier, D. P.: Surface soil moisture parameterization of the VIC-2L model: Evaluation and modification, Global Planet. Change, 13, 195-206, 1996.

Liao, Z., Hong, Y., Wang, J., Fukuoka, H., Sassa, K., Karnawati, D., and Fathani, F.: Prototyping an experimental early warning system for rainfall-induced landslides in Indonesia using satellite remote sensing and geospatial datasets, Landslides, 7, 317-324, 2010.

Lin, Y. and Mitchell, K. E.: The NCEP Stage II/IV hourly precipitation analyses: development and applications, 19th Conference on Hydrology, American Meteorological Society, San Diego, CA, 9-13 January, 2005.

Lu, N. and Godt, J.: Infinite slope stability under steady unsaturated seepage conditions, Water Resour. Res., 44, 2276-2283, 2008.

May, F.: Cascading disaster models in Postburn flash flood, The fire environment-innovations, management, and policy, Destin, FL, 26-30 March 2007

Mignan, A., Wiemer, S., and Giardini, D.: The quantification of low-probability-high-consequences events: part I. A generic multi-risk approach, Nat. Hazards, 73, 1999-2022, 2014.

National Oceanic and Atmospheric Administration: Storm data, National Climatic Data Center, 46, 1-262, 2004.

Raia, S., Alvioli, M., Rossi, M., Baum, R. L., Godt, J. W., and Guzzetti, F.: Improving predictive power of physically based rainfall-induced shallow landslide models: a probabilistic approach, Geosci. Model Dev., 7, 495-514, doi:10.5194/gmd-7495-2014, 2014.

Shen, X., Hong, Y., Zhang, K., and Hao, Z.: Refining a distributed linear reservoir routing method, J. Hydrol. Eng., 04016061, doi:10.1061/(ASCE)HE.1943-5584.0001442, 2016.

Simoni, S., Zanotti, F., Bertoldi, G., and Rigon, R.: Modelling the probability of occurrence of shallow landslides and channelized debris flows using GEOtop-FS, Hydrol. Process., 22, 532-545, doi:10.1002/hyp.6886, 2008.

Spiker, E. C. and Gori, P. L.: National landslide hazards mitigation strategy - a framework for loss reduction, US Department of the Interior and US Geological Survey, Reston, Virginia, 2003.

Srivastava, R. and Yeh, T. C. J.: Analytical Solutions for OneDimensional, Transient Infiltration toward the Water-Table in Homogeneous and Layered Soils, Water Resour. Res., 27, 753762, doi:10.1029/90wr02772, 1991.

Sugawara, M., Watanabe, I., Ozaki, E., and Katsugama, Y.: Tank model with snow component. Research Notes of the National Research Center for Disaster Prevention No. 65, Science and Technolgoy, Ibaraki-Ken, Japan, 1984.

Tao, J. and Barros, A. P.: Coupled prediction of flood response and debris flow initiation during warm- and cold-season events in the Southern Appalachians, USA, Hydrol. Earth Syst. Sci., 18, $367-$ 388, doi:10.5194/hess-18-367-2014, 2014.

Terzaghi, K., Peck, R., and Mesri, G.: Soil Mechanics in Engineering Practice, Wiley, New York, 1996.

Uccellini, L. W., Suffern, P., Harding, K., Brown, V., Keeney, J., Stammer, K., and Stefkovich, J.: Service assessment: May 2013 Oklahoma tornadoes and flash flooding, US Department of Commerce, National Oceanic and Atmospheric Administration, National Weather Service, Silver Spring, Maryland, 42, 2014.

Wang, J. H., Yang, H., Li, L., Gourley, J. J., Sadiq, I. K., Yilmaz, K. K., Adler, R. F., Policelli, F. S., Habib, S., Irwn, D., Limaye, A. S., Korme, T., and Okello, L.: The coupled routing and excess storage (CREST) distributed hydrological model, Hydrolog. Sci. J., 56, 84-98, 2011.

Wastl, M., Stotter, J., and Kleindienst, H.: Avalanche risk assessment for mountain roads: a case study from Iceland, Nat. Hazards, 56, 465-480, 2011. 
Wigmosta, M. S., Vail, L. W., and Lettenmaier, D. P.: A distributed hydrology-vegetation model for complex terrain - Reply, Water Resour. Res., 32, 213-214, 1996.

Williams, J. R. and Hann, R. W.: Optimal operation of large agricultural watersheds with water quality constraints. Technical Report No. 96., Texas Water Resoources Institute, Texas A\&M University, 1978.

Wooten, R. M., Gillon, K. A., Witt, A. C., Latham, R. S., Douglas, T. J., Bauer, J. B., Fuemmeler, S. J., and Lee, L. G.: Geologic, geomorphic, and meteorological aspects of debris flows triggered by Hurricanes Frances and Ivan during September 2004 in the Southern Appalachian Mountains of Macon County, North Carolina (southeastern USA), Landslides, 5, 31-44, 2008.

Wu, H., Adler, R. F., Tian, Y. D., Huffman, G. J., Li, H. Y., and Wang, J. J.: Real-time global flood estimation using satellitebased precipitation and a coupled land surface and routing model, Water Resour. Res., 50, 2693-2717, 2014.

Xue, X., Hong, Y., and Zhang, K.: CREST User Manual, in, University of Oklahoma, Norman, Oklahoma, USA, 63, 2015.

Xue, X. W., Hong, Y., Limaye, A. S., Gourley, J. J., Huffman, G. J., Khan, S. I., Dorji, C., and Chen, S.: Statistical and hydrological evaluation of TRMM-based Multi-satellite Precipitation Analysis over the Wangchu Basin of Bhutan: Are the latest satellite precipitation products $3 \mathrm{~B} 42 \mathrm{~V} 7$ ready for use in ungauged basins?, J. Hydrol., 499, 91-99, 2013.

Yao, C., Li, Z., Yu, Z. B., and Zhang, K.: A priori parameter estimates for a distributed, grid-based Xinanjiang model using geographically based information, J. Hydrol., 468-469, 47-62, 2012.
Yu, Z. B., Lu, Q. G., Zhu, J. T., Yang, C. G., Ju, Q., Yang, T., Chen, X., and Sudicky, E. A.: Spatial and Temporal Scale Effect in Simulating Hydrologic Processes in a Watershed, J. Hydrol. Eng., 19, 99-107, 2014.

Zhang, K., Kimball, J. S., Mu, Q., Jones, L. A., Goetz, S. J., and Running, S. W.: Satellite based analysis of northern ET trends and associated changes in the regional water balance from 1983 to 2005, J. Hydrol., 379, 92-110, 2009.

Zhang, K., Kimball, J. S., Nemani, R. R., and Running, S. W.: A continuous satellite-derived global record of land surface evapotranspiration from 1983 to 2006, Water Resour. Res., 46, W09522, doi:10.1029/2009WR008800, 2010.

Zhang, K., Kimball, J. S., Nemani, R. R., Running, S. W., Hong, Y., Gourley, J. J., and Yu, Z. B.: Vegetation Greening and Climate Change Promote Multidecadal Rises of Global Land Evapotranspiration, Scientific Reports, 5, 15956, doi:10.1038/srep15956, 2015.

Zhang, Y., Hong, Y., Wang, X. G., Gourley, J. J., Xue, X. W., Saharia, M., Ni, G. H., Wang, G. L., Huang, Y., Chen, S., and Tang, G. Q.: Hydrometeorological Analysis and Remote Sensing of Extremes: Was the July 2012 Beijing Flood Event Detectable and Predictable by Global Satellite Observing and Global Weather Modeling Systems?, J. Hydrometeorol., 16, 381-395, 2015.

Zhao, R. J.: The Xinanjiang model applied in China, J. Hydrol., 135, 371-381, 1992.

Zhao, R. J., Zhuang, Y. G., Fang, L. R., Liu, X. R., and Zhang, Q. S.: The Xinanjiang Model, Hydrological Forecasting Proceedings Oxford Symposium, 1980. 